\title{
The Effect of Low Birth Weight and Age on the Cognitive Performance of Preterm Preschoolers
}

\author{
Seo-Yoon Lee', Aran Min', Hyun Ju Lee ${ }^{2}$, Hyewon Park ${ }^{3}$, \\ Mi-Young $\mathrm{Oh}^{1}$, Ji-Hyun $\mathrm{Cho}^{4}$, and Dong-Hyun $\mathrm{Ahn}^{1,5}$ \\ ${ }^{1}$ Department of Psychiatry, Hanyang University Hospital, Seoul, Korea \\ ${ }^{2}$ Department of Pediatrics, Hanyang University College of Medicine, Seoul, Korea \\ ${ }^{3}$ Department of Child \& Family Welfare, University of Ulsan, Ulsan, Korea \\ ${ }^{4}$ Hyundai Sarang Hospital, Changwon, Korea \\ ${ }^{5}$ Department of Psychiatry, Hanyang University College of Medicine, Seoul, Korea
}

\section{조산아의 저출생체중과 연령이 학령전기 인지수행에 미치는 영향}

\author{
이서윤 ${ }^{1}$, 민아란 $^{1}$, 이현주 ${ }^{2}$, 박혜원 $^{3}$, 오미영 ${ }^{1}$, 조지현 ${ }^{4}$, 안동현 $^{1,5}$ \\ 한양대학교병원 정신건강의학과, ${ }^{1}$ 한양대학교 의과대학 소아과학교실, ${ }^{2}$ 울산대학교 아동가정복지학과, ${ }^{3}$ \\ 현대사랑병원, ${ }^{4}$ 한양대학교 의과대학 정신건강의학교실 ${ }^{5}$
}

\begin{abstract}
Objectives: The current study examined the effect of birth weight on the relationship between age and IQ of children, who were born preterm with very low birth weight (VLBW) or extremely low birth weight (ELBW).

Methods: The study subjects were 82 children, aged between 3-5 years, who visited the neonatal intensive care unit of a university hospital located in Seoul. The children had been born prematurely with VLBW or ELBW. Their IQ was tested using the performed KoreanWechsler Preschool and Primary Scale of Intelligence fourth edition.

Results: A hierarchical regression analysis showed a significant interaction effect of birth weight and age on Full Scale IQ (FSIQ); the effect of age on FSIQ differed according to birth weight. For the group with VLBW, FSIQ was more likely to be higher with increasing age. Conversely, for the group with ELBW, FSIQ remained low regardless of the age level. In addition, birth weight and age had a significant interaction effect on the Visual Spatial Index. Birth weight had a significant main effect on Verbal Comprehension Index.

Conclusion: This research suggested the possibility of predicting the cognitive developmental of premature children, by highlighting the fact that prematurely born children, with VLBW/ELBW, have different cognitive developmental trajectories.
\end{abstract}

Key Words: K-WPPSI-IV; Cognitive development; Premature birth; Extremely low birth weight; Very low birth weight.

Received: December 13, 2016 / Revision: January 12, 2017 / Accepted: February 4, 2017

Address for correspondence: Dong-Hyun Ahn, Department of Psychiatry, Hanyang University College of Medicine, 222 Wangsimni-ro, Seongdong-gu, Seoul 04763, Korea

Tel: +82-2-2290-8425, Fax: +82-2-2298-2055, E-mail: ahndh@hanyang.ac.kr

\section{서 론}

신생아와 관련된 의학기술의 발전으로 저출생체중아나 조 산아의 생존율이 증가하고 있으며, 이들의 인지적 능력의 발 달에 대한 관심 역시 고조되고 있다. 조산아는 태아가 자궁에 서 발달하는 재태기간이 37주 미만인 아동이라고 정의할 수 있으며, ${ }^{1)}$ 재태기간에 따라 extremely preterm infant(28주 미 만), very preterm infant(28주 이상 32주 미만), moderate to

This is an Open Access article distributed under the terms of the Creative Commons Attribution Non-Commercial License (http://creativecommons.org/licenses/by-nc/4.0) which permits unrestricted non-commercial use, distribution, and reproduction in any medium, provided the original work is properly cited. late preterm infant(32주 이상 37주 미만)로 세분할 수 있다. ${ }^{2)}$ 또한 조산 여부와 독립적으로 출생체중이 $2500 \mathrm{~g}$ 이하일 경우 저출생체중아라고 하는데, 특히 $1500 \mathrm{~g}$ 미만인 경우에는 극소 저출생체중아(very low birth weight, VLBW), $1000 \mathrm{~g}$ 미만인 신생아는 초극소저출생체중아(extreme low birth weight, ELBW)로 분류할 수 있다.3) 아동의 발달 지연 위험을 높이는 여러 위험 요인들 중 낮은 출생체중은 생물학적인 발달적 취 약성으로 분류되며, 신경발달학적 위험 요인인 조산아의 저체 중은 인지능력 발달에도 부정적인 영향을 주는 것으로 보인다. 선행연구를 살펴보면, VLBW는 통제집단에 비해 신경심리학 적 결함이나 행동적 장애들이 높게 나타났고 지능평가 결과에 
서도 정상체중아보다 유의한 수준으로 낮게 나타났다.") 또 다 른 연구에서도 출생체중이 $750 \mathrm{~g}$ 미만이었던 중학생 집단은 출생체중이 750 1499 g이었던 집단에 비해 인지기능, 학업 수 행이 통제집단에 비해 유의한 수준으로 낮게 나타났으며, 지적 장애에 해당하는 수준의 지적 기능을 가진 경우도 9.5배 높았 다고 보고되었다.5) 이와 함께 극소저출생체중아에게 6세경 실 시한 Wechsler Preschool and Primary Scale of Intelligence (WPPSI)의 언어적 영역의 점수가 통제집단에 비해 유의하게 낮았다고 보고되었다. ${ }^{6}$ WPPSI-revised로 지능을 평가한 연 구에서도 극소저출생체중아가 언어성 지능, 동작성 지능, 전 체지능 모두 만삭 아동에 비해 유의하게 낮게 나타났다는 결 과가 있다.) 더불어 최근 출생 시 저체중이거나 미숙아와 같은 생물학적 취약성이 있는 고위험군인 영유아를 대상으로 WPPSI-IV를 실시한 연구에서도, 전체지능 및 세부인지 영역 에서 정상집단에 비해 모두 유의하게 낮은 것으로 나타났다. ${ }^{8}$

이러한 조산아의 인지적 발달을 평가할 때에는 시간적 요 인을 고려해야 할 필요가 있는데, 유아 초기의 인지적 수준과 유아 후기에 평가된 인지적 수준이 다를 수 있기 때문이다. 보 다 미세한 인지기능 저하는 영유아 초기에는 감별하기 어렵 고 일반적으로 더 늦은 유아 중기 이후에 나타난다. 미숙아를 대상으로 진행된 한 종단 연구에 따르면, 30 개월경 인지기능 에서의 장애가 없었던 점은 6세경 인지 발달 문제에 대한 예 측력이 거의 없었다고 보고되었다. ${ }^{9}$ 또 다른 연구에 따르면 27 주 이전에 태어난 조산아가 2.5세경에 경하거나 장애가 없었 다고 보고되었으나, ${ }^{10)}$ 미숙아인 영유아를 추적 관찰할수록 지 적 손상에 대한 비율이 점차 높아졌다는 연구가 있다. ${ }^{11}$ 또한 대규모 추적 연구에서 재태기간 33주 전에 태어난 조산아 중 출생 당시 유의한 수준의 뇌손상이 없었으나, 이와는 독립적 인 인지 결함이 추적 관찰 중 보고되었고 취약한 인지기능과 언어적 수행이 나타났다. ${ }^{12)}$ 즉, 추적 관찰 중 지적 능력의 결함 정도가 변화할 수 있기 때문에, 조산아의 인지적 능력을 신뢰 롭게 평가하기 위해서는 수년의 추적이 필요할 수 있다. ${ }^{13)}$ 따라 서 조산아의 신경발달이나 인지기능의 발달에 대해 정확한 평 가를 하기 위해서는 출생 후 연령을 고려한 평가가 필요할 것 으로 보인다.

한편, 한국 웩슬러 유아지능평가 4판(Korean-Wechsler Preschool and Primary Scale of Intelligence fourth edition, KWPPSI-IV)은 2세 6개월 7세 7개월의 연령범위에 해당하는 영유아의 지능을 측정하는 평가도구이다. ${ }^{14)}$ 웩슬러 지능평가 도구는 많은 연구에 의해 타당도와 임상적 유용성이 경험적 으로 입증되어 왔으며,15) K-WPPSI-IV의 주요한 구성개념에 는 신경심리학적인 인지처리능력과 관련된 가설이 포함되어 있어 인지신경발달학적 예후지표로도 유용할 것으로 보인
다. ${ }^{16-18)}$ 또한 K-WPPSI-IV는 다른 영유아 대상의 발달검사에 비해 상대적으로 넓은 연령범위를 포괄하여 일관성 있는 비 교에 유리하다. 뿐만 아니라 2세 6개월 3세 11개월용과 4세 0 개월 7세 7개월용으로 검사체계를 구별하여, 유아의 피로도 를 줄이면서도 발달 수준에 적합한 평가 과제를 체계적으로 수행할 수 있도록 고안되었다. 이를 통해 인지 및 신경발달적 변화가 급격하게 이루어지는 영유아의 인지기능을 타당하게 평가할 수 있다. ${ }^{8)}$ 아울러 표준화된 시행 및 절차에 의해 산출 된 환산 점수를 통해 아동 간의 수행이나 한 아동의 시간의 흐름에 따른 수행을 규준집단에 근거하여 비교할 수 있다. 영 유아의 지능은 단일 측정보다는 연령에 따라 여러 차례 측정 할 때 보다 정확한 판단을 할 수 있음을 고려해 볼 때,9) 상기 검사는 영유아의 발달 경과를 확인하고 연구하기에 적합하다 고 할 수 있다.

국내 연구를 살펴보면, 조산아나 저체중아의 영유아기 지능 에 관한 연구는 드물며, 특히 $1500 \mathrm{~g}$ 미만의 극소저출생체중 아나 초극소저출생체중아의 지능에 대한 연구는 전무하다. 다만, 영유아 발달검사(Bayley Scales of Infant and Toddler Development)를 통해 시행된 연구는 소수 존재하는데, 이 검 사의 발달 지수는 지능 지수와 동일한 개념은 아니나, ${ }^{20)}$ 전 세 계적으로 사용되고 있는 WPPSI-IV와 중상 정도의 상관관계 가 있다고 알려졌다. ${ }^{8)}$ 따라서 조산아 집단이 만삭아 집단에 비해 언어, 인지, 운동 영역의 발달 지수가 모두 유의하게 낮 은 것으로 보고된 국내 연구의 결과 ${ }^{21)}$ 는 앞서 언급한 선행연 구들과 맥을 같이하는 것으로 볼 수 있겠다.

앞서 언급한 여러 선행연구에서 신경발달학적 손상이나 인지 적 장해에 대한 고위험군으로 알려진 초극소/극소저출생체중 아는 인지적 발달의 예후를 관찰하기 위해 지능 발달에 대한 정확한 평가가 필요할 것으로 보이나, 이와 관련된 연구가 부 족한 실정이다. 이에 본 연구의 목적은 초극소/극소저출생체 중아로 출산된 영유아의 지능을 검증된 최신판 지능평가도구 인 K-WPPSI-IV를 통해 살펴봄으로써, 미숙아의 출생체중과 연령이 지능에 미치는 영향을 살펴보는 것이다. 구체적으로 출생체중과 연령에 따라 인지 발달의 궤도가 다른 양상을 띨 것으로 보고, 전체지능과 연령 간의 관계에서 출생체중의 상 호작용 효과가 존재할 것이라는 가설을 설정하였다. 이와 함 께 세부인지 영역에 대한 출생체중과 연령의 영향을 탐색적으 로 살펴보았다.

\section{방 법}

\section{대 상}

본 연구의 대상은 조산아 중 초극소/극소저출생체중아로 태 
어난 3 5세의 유아 82명이다. 서울 소재의 한양대학교병원의 신생아중환자실에 2010년 1월부터 2012년 1월 사이에 입원하 였던 조산아 중 출생체중이 $1500 \mathrm{~g}$ 미만이었던 영유아를 경 과 관찰하던 중 모집되었다. 연구 참여에 대한 동의 및 협조가 가능한 대상만 모집되면서 연구 대상의 조건에 부합하였으나 본 연구에 참여하지 못한 경우가 81명이 있었는데, 이들은 연 구 참여 거부(23명), 이사(18명), 사망(16명), 경과 관찰 중단(9 명), 다른 연구 참여(9명), 유아의 협조 실패(6명)와 같은 사유로 인해 본 연구에 불참하였다. 연구 참여자의 기본적인 인구통 계학적 특징은 Table 1 과 같다.

\section{절 차}

본 연구는 본원 임상시험검사위원회의 승인을 받았다(IRB No. HYUH 2015-02-014). 연구 참여를 희망한 보호자에게 연구 배경 및 목적, 과정, 참여로 인한 위험성 및 불편사항, 혜 택에 대한 안내가 먼저 이루어졌고, 이에 대한 동의를 한 보 호자의 영유아에 한해서 지능평가를 시행하였다. 검사자는 아동발달학 전공 중인 대학원생 2 명이 표준화된 절차에 따라 시행하였다. 검사자들은 8시간씩 2회기로 구성된 K-WPSSIIV 워크숍을 이수하여 이를 충분히 숙지하였다. 또한 유아의 인지기능 발달 수준을 포함한 연구 검사의 결과에 대한 피드 백을 보호자에게 제공하였다.

\section{측정 도구}

한국 웩슬러 유아지능평가 4판(Korean-Wechsler Preschool and Primary Scale of Intelligence fourth edition, K-WPPSI-IV)

한국 웩슬러 유아지능평가 4판(K-WPPSI-IV)은 만 2세 6개 월 7세 7개월 사이(2:6 7:7) 영유아의 인지능력을 임상적으로

Table 1. Demographic characteristics of participants $(n=82)$

\begin{tabular}{lc}
\hline \multicolumn{1}{c}{ Characteristics } & Participants \\
\hline Age, months, M (SD) & $50.2(12.4)$ \\
Gestational age, day, M (SD) & $200.3(18.3)$ \\
Birth weight, $\mathrm{n}(\%)$ & \\
ELBW & $34(41.5)$ \\
VLBW & $48(58.5)$ \\
Sex, $\mathrm{n}(\%)$ & \\
$\quad$ Male & $39(47.60)$ \\
Female & $43(52.40)$ \\
Mother's education, $\mathrm{n}(\%)$ & \\
$\geq$ college level & $43(52.4)$ \\
$\leq$ high school level & $38(46.3)$ \\
No answer & $1(1.2)$
\end{tabular}

ELBW: extremely low birth weight, $M$ : mean, n: number, SD: standard deviation, VLBW: very low birth weight
평가할 수 있도록 개발된 지능평가도구로서, 최신 개정판인 웩 슬러 유아지능평가 4판 ${ }^{8}$ 을 국내에서 Park 등 ${ }^{22}$ 이 표준화한 것 이다. K-WPPSI-IV는 전반적인 인지능력을 나타내는 전체지 능뿐 아니라 세부 인지 영역의 기능을 나타내는 지표 점수를 연령의 발달 수준에 맞게 산출할 수 있다(Table 2). 주요한 세 부 인지 영역은 총 5 가지이며 설명은 다음과 같다. 언어이해 지 표는 획득된 지식과 언어적 이해 및 개념 형성과 관련된 능력 과 관련되며, 전반적인 언어적 지능을 반영한다. ${ }^{16-18)}$ 유동추론 지표는 시각적 자극을 통해 개념적인 사고와 범주화 능력, 동 시적인 처리능력과 관련되며 전반적인 비언어적 지능을 반영 한다. ${ }^{16-18)}$ 시공간지표는 시각-공간적 처리와 부분 및 전체의 관계를 통합하는 능력을 반영하며, 앞서 언급한 언어이해 및 유동추론 영역과 함께 문제해결, 인지적 유연성, 추론 및 계 획 능력과 같은 실행기능과 관련된다. ${ }^{16-18)}$ 작업기억지표는 순 간적인 시각적 정보에 대한 즉각적인 학습 및 기억력을 측정 하며, 처리속도 지표는 보다 단순한 시각적 정보를 빠르게 변 별하고 처리하는 능력을 측정한다. ${ }^{16-18)}$ 한국 웩슬러 유아지능 평가의 Cronbach's $\alpha$ 는 0.92로 나타났다. ${ }^{14)}$

\section{자료 분석}

SPSS 22.0(SPSS Inc., Chicago, IL, USA)을 통해 다음의 방법으로 분석하였다. 첫째로 인구통계학적 변인들을 분석하 기 위해 기술통계를 사용하였다. 둘째로 주요 변인들 간 관계 를 상관분석을 통해 살펴보았다. 셋째로 전체지능과 세부 인 지지표를 각각 종속변인으로, 연령과 출생체중을 독립변인으 로 하여 주효과와 상호작용 효과를 위계적 회귀분석을 통해 검증하였다. 1단계에서 통제변인인 성별을 투입하였고, 2단계 에서 출생체중과 연령, 3 단계에서 출생체중과 연령의 상호작 용항을 투입하였다. 성별은 남과 여, 출생체중은 초극소저출 생체중아와 극소저출생체중아를 구분하여 더미변수로 변환 하였고, 연속변수인 연령은 상호작용 효과를 확인하는 과정

Table 2. Primary composite score of K-WPPSI-IV

\begin{tabular}{|c|c|c|}
\hline \multirow{2}{*}{$\begin{array}{l}\text { Composite } \\
\text { score }\end{array}$} & \multicolumn{2}{|c|}{ Age } \\
\hline & $\begin{array}{l}2 \text { yrs } 6 \text { month } \\
-3 \text { yrs } 11 \text { month }\end{array}$ & 4 yrs -7 yrs 7 month \\
\hline$\overline{F S I Q}$ & V & V \\
\hline $\mathrm{VCl}$ & V & V \\
\hline VSI & V & V \\
\hline WMI & V & V \\
\hline FRI & & $\vee$ \\
\hline PSI & & $\vee$ \\
\hline
\end{tabular}

FRI: Fluid Reasoning Index, FSIQ: Full Scale Intelligence Quotient, K-WPPSI-IV: Korean-Wechsler Preschool and Primary Scale of Intelligence fourth edition, PSI: Processing Speed Index, VCl: Verbal Comprehension Index, VSI: Visual Spatial Index, WMI: Working Memory Index 
에서 발생할 수 있는 다중공선성 문제를 해결하기 위해 평균 화(centering)를 하였다. ${ }^{23)}$ 본 연구의 표본 크기는 총 82 명으 로, 앞서 언급한 위계적 회귀분석에서 투입된 독립변인의 수 를 고려하여 $\mathrm{Soper}^{24}$ 의 애플릿을 통해 산출한 최소 표본 크기
를 충족하였다(효과크기 0.15 , 검정력 0.80 , 유의도 수준 0.05 ). 다만, 세부 인지 영역의 위계적 회귀분석에 있어서 저연령과 고 연령에게 공통된 영역인 언어이해, 시공간, 처리속도 지표만 분 석에 포함되었다.

Table 3. M, SD, and correlation coefficient between composite score and birth weight/sex

\begin{tabular}{lccccc}
\hline & Birth weight & Age & Sex & M & SD \\
\hline FSIQ $(n=82)$ & $0.253^{*}$ & 0.146 & 0.02 & 95.61 & 13.19 \\
VCI $(n=82)$ & $0.263^{*}$ & -0.013 & 0.105 & 93.30 & 12.64 \\
VSI $(n=82)$ & 0.185 & $0.405^{\dagger}$ & -0.035 & 100.21 & 17.63 \\
WMI $(n=82)$ & -0.012 & 0.053 & -0.131 & 98.44 & 14.46 \\
FRI $(n=40)$ & 0.168 & $0.312^{*}$ & -0.064 & 93.15 & 17.64 \\
PSI $(n=40)$ & 0.296 & -0.089 & 0.075 & 97.98 & 16.56
\end{tabular}

${ }^{*} \mathrm{p}<0.05,{ }^{\dagger} \mathrm{p}<0.01$. FRI: Fluid Reasoning Index, FSIQ: Full Scale Intelligence Quotient, M: mean, PSI: Processing Speed Index, SD: standard deviation, $\mathrm{VCl}$ : Verbal Comprehension Index, VSI: Visual Spatial Index, WMI: Working Memory Index

Table 4. Hierarchical regression analysis between composite score and birth weight/sex

\begin{tabular}{|c|c|c|c|c|c|}
\hline Dependent variables & Model & Independent variables & $\beta$ & $R^{2}$ & $\Delta R^{2}$ \\
\hline \multirow[t]{8}{*}{$\mathrm{FSIQ}(\mathrm{n}=82)$} & 1 & Sex & 0.020 & 0.000 & 0.000 \\
\hline & 2 & Sex & 0.053 & $0.075^{*}$ & $0.075^{*}$ \\
\hline & & Age & 0.090 & & \\
\hline & & Birth weight & $0.241^{*}$ & & \\
\hline & 3 & Sex & 0.056 & $0.121^{*}$ & $0.046^{*}$ \\
\hline & & Age & -0.178 & & \\
\hline & & Birth weight & $0.260^{*}$ & & \\
\hline & & Birth weight $\times$ age & $0.340 *$ & & \\
\hline \multirow[t]{8}{*}{$\mathrm{VCl}(\mathrm{n}=82)$} & 1 & Sex & 0.105 & 0.011 & 0.011 \\
\hline & 2 & Sex & 0.158 & $0.098^{*}$ & $0.087^{*}$ \\
\hline & & Age & -0.089 & & \\
\hline & & Birth weight & $0.307^{\dagger}$ & & \\
\hline & 3 & Sex & 0.159 & 0.104 & 0.005 \\
\hline & & Age & -0.181 & & \\
\hline & & Birth weight & $0.313^{\dagger}$ & & \\
\hline & & Birth weight $\times$ age & 0.117 & & \\
\hline \multirow[t]{8}{*}{ VSI $(n=82)$} & 1 & Sex & -0.035 & 0.001 & 0.001 \\
\hline & 2 & Sex & -0.042 & $0.175^{\ddagger}$ & $0.174^{\ddagger}$ \\
\hline & & Age & $0.386^{\ddagger}$ & & \\
\hline & & Birth weight & 0.094 & & \\
\hline & 3 & Sex & -0.039 & 0.228 & $0.052^{*}$ \\
\hline & & Age & 0.100 & & \\
\hline & & Birth weight & 0.114 & & \\
\hline & & Birth weight $\times$ age & $0.364^{*}$ & & \\
\hline \multirow[t]{8}{*}{ WMI $(n=82)$} & 1 & Sex & -0.131 & 0.017 & 0.017 \\
\hline & 2 & Sex & -0.143 & & \\
\hline & & Age & 0.072 & 0.023 & 0.006 \\
\hline & & Birth weight & -0.050 & & \\
\hline & 3 & Sex & -0.141 & 0.033 & 0.010 \\
\hline & & Age & -0.052 & & \\
\hline & & Birth weight & -0.042 & & \\
\hline & & Birth weight $\times$ age & 0.158 & & \\
\hline
\end{tabular}




\section{결 과}

전체지능 및 지표 점수와 성별, 연령, 출생체중 사이의 상관 계수를 Table 3에 제시하였다. 상관분석 결과, 출생체중과 유 의한 상관관계를 보인 것은 전체지능과 언어이해 지표였으며 $(\mathrm{r}=0.253, \mathrm{p}<0.05 ; \mathrm{r}=0.312, \mathrm{p}<0.05)$, 연령과 유의한 상관관계로 나타난 것은 시공간지표와 유동추론지표였다 $(\mathrm{r}=0.405, \mathrm{p}<0.001$; $\mathrm{r}=0.312, \mathrm{p}<0.05)$. 성별은 전체지능 및 지표 점수와 유의한 상 관관계가 나타나지 않았다. 다만 추가분석을 시행한 결과, 성별 은 언어이해 영역의 소검사인 수용어휘와 유의한 수준의 상관 관계가 나타났다 $(\mathrm{r}=0.223, \mathrm{p}<0.05)$.

다음으로 지능에 대한 연령과 출생체중의 영향력을 알아보 기 위해 위계적 회귀분석을 실시하였고, 결과는 Table 4에 제시 하였다. 앞서 언급한 성별과 수용어휘 소검사 점수와의 유의한 상관관계와 더불어, 남아가 여아에 비해 상대적으로 인지 발달 문제가 더 많으며) 시각적 기억력이나 정확성이 요구되는 과제 에서 더 저조한 수행을 보였다는 선행연구가 있었다. ${ }^{25)}$ 이를 고 려하여 1단계에서 성별을 통제변인으로 투입하였으나, 본 연구 에서는 성별의 영향력이 모두 유의하지 않은 것으로 나타났다 $\left(\mathrm{R}^{2}=0.000 \sim 0.017, \mathrm{NS}\right)$.

주요 결과를 살펴보면, 전체지능에 대한 출생체중의 주 효과 는 물론 $(\beta=0.260, p<0.05)$, 연령과 출생체중의 상호작용 효과 가 유의하여 $(\beta=0.340, p<0.05)$, 연령이 지능에 미치는 효과는 출생체중의 수준에 따라 다르게 나타났다. 단계 2 와 3 에서의 설 명변량 $\left(\mathrm{R}^{2}\right)$ 은 각각 $7.5 \%$ 와 $12.1 \%$ 로서 상호작용 효과에 따른 설 명변화량은 약 $4.6 \%$ 였다 $\left(\Delta \mathrm{R}^{2}=0.046, \mathrm{p}<0.05\right)$. 상호작용 효과 를 시각적으로 이해하기 위해, 연령과 출생체중의 각각 \pm 1 표 준편차를 기준으로 구분하여 ${ }^{23)}$ 그래프로 나타내었다(Fig. 1).

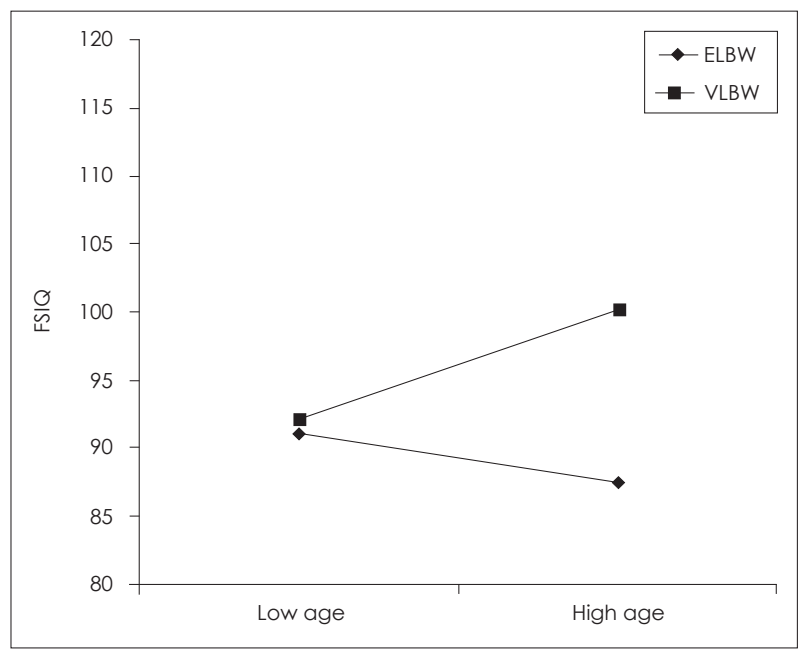

Fig. 1. Birth weight $\times$ age interaction effect on FSIQ. ELBW: extremely low birth weight, FSIQ: Full Scale Intelligence Quotient, VLBW: very low birth weight.
초극소저출생체중아와 같이 출생체중이 극히 낮은 경우는 연 령에 따른 전체지능의 변화가 유의하지 않았으나, 상대적으로 출생체중이 더 높은 극소저출생체중아와 같은 경우에는 연령 이 증가함에 따라 전체지능이 상승하는 경향이 나타났다.

더불어 세부 인지 영역별로 출생체중과 연령이 미치는 영향 을 살펴보기 위해, 각 지표점수를 종속변수로 투입하여 동일 한 방식의 위계적 회귀분석을 진행하였다. 그 결과 언어이해 영 역에서는 출생체중의 주 효과가 유의하게 나타났는데 $(\beta=0.307$, $\mathrm{p}<0.05)$, 이로 인한 설명변화량은 총 $8.7 \%$ 였다 $\left(\Delta \mathrm{R}^{2}=0.087, \mathrm{p}<\right.$ 0.05). 즉, 언어이해 지표는 연령 수준과 상관없이 출생체중이 상대적으로 더 높은 극소저출생체중아가 초극소저출생체중 아에 비해 더 높은 점수를 보였다(Fig. 2). 다음으로 시공간 영 역에서는 연령과 출생체중의 상호작용 효과가 유의하였는데

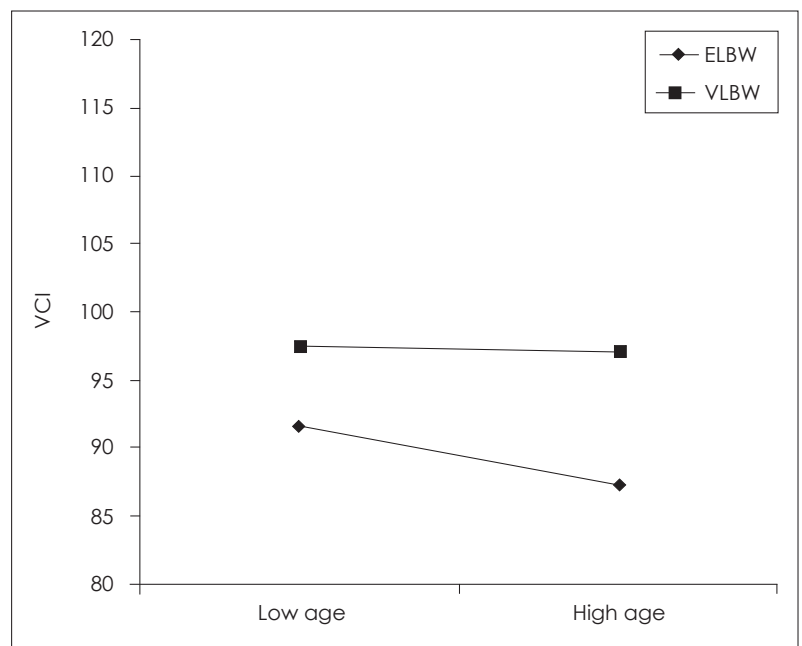

Fig. 2. Main effect of birth weight on VCl. ELBW: extremely low birth weight, VCl: Verbal Comprehension Index, VLBW: very low birth weight.

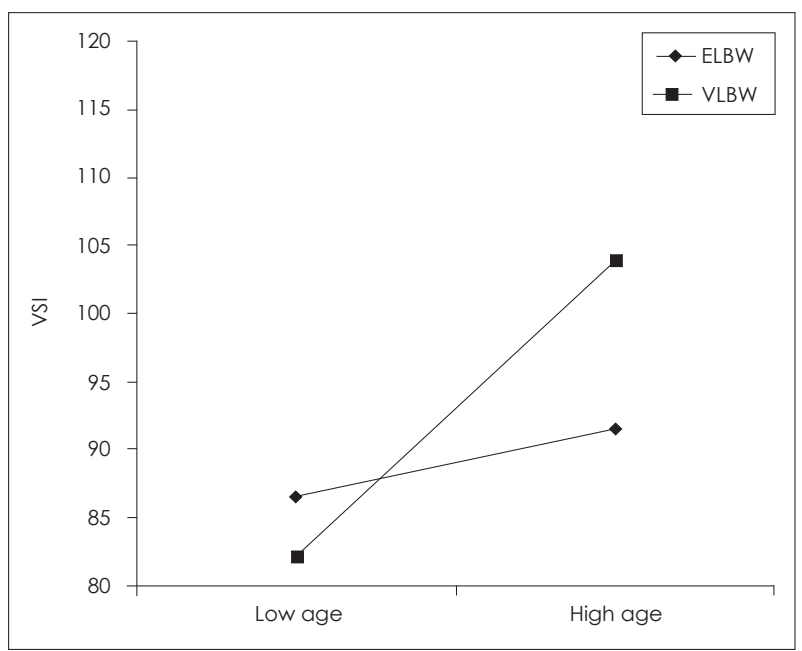

Fig. 3. Birth weight $\times$ age interaction effect on VSI. ELBW: extremely low birth weight, VLBW: very low birth weight, VSI: Visual Spatial Index. 
$(\beta=0.386, p<0.001)$, 단계 2와 3에서의 설명량 $\left(R^{2}\right)$ 은 각각 $17.5 \%$ 와 $22.8 \%$ 로 상호작용 효과에 따른 설명변화량은 약 $5.2 \%$ 였 다 $\left(\Delta \mathrm{R}^{2}=0.052, \mathrm{p}<0.05\right)$. Fig. 3 과 같이 연령이 시공간 영역에 미치는 영향은 출생체중의 수준에 따라 다르게 관찰되었다. 즉, 초극소저출생체중아와 같이 출생체중이 극히 낮은 경우 는 연령에 따른 시공간능력의 변화가 크지 않았으나, 극소저출 생체중아와 같이 상대적으로 출생체중이 더 높은 경우에는 연령이 증가함에 따라 시공간 능력이 높아지는 양상을 보였다. 한편, 작업기억지표에 대한 연령과 출생체중의 영향을 살펴보 기 위해 위계적 회귀분석을 시행하였으나, 단계 1 의 성별은 물 론 $\left(\mathrm{R}^{2}=0.017, \mathrm{NS}\right) .2$ 단계의 연령, 출생체중의 주 효과 $\left(\Delta \mathrm{R}^{2}=\right.$ $0.006, \mathrm{NS})$ 나, 단계 3 의 연령과 출생체중의 상호작용 효과 모 두 유의하지 않았다 $\left(\Delta R^{2}=0.010, N S\right)$.

\section{고 찰}

본 연구의 목적은 타당한 지능평가도구를 통해 조산아의 지능에 출생체중과 연령이 미치는 영향을 살펴보는 것이다. 서두에서 밝힌 연구의 가설은 전체지능과 연령 간의 관계에 서 출생체중의 상호작용 효과가 존재한다는 것이었다. 본 연 구의 결과는 가설대로 조산아의 전체지능과 연령 간의 관계 에서 출생 시 체중의 상호작용 효과가 유의한 것으로 나타났 다. 즉, 조산아 중 출생체중이 낮은 경우에는 연령과 관계없이 전체지능에서의 변화가 크지 않은 것으로 나타났으나, 출생체 중이 상대적으로 더 높은 경우에는 연령이 상승함에 따라 높 은 지능이 나타났다. 이는 초극소/극소저출생체중아의 지능은 연령이 낮을 때에는 차이가 두드러지지 않더라도, 극소저출생 체중아의 경우에는 연령이 증가함에 따라 전체지능에 대한 발 달 지연이 가역적으로 회복되는 경과를 보일 가능성이 있음 을 의미한다. 결국, 본 연구의 가설대로 영유아의 출생체중에 따라 인지 발달의 궤도가 다른 양상을 보이는 것으로 나타났 으며, 이는 치료적 개입에 있어서 출생체중의 수준에 따라 차 별적인 접근이 필요할 가능성을 제기한다.

더불어 출생체중과 연령에 따라 세부 인지 영역별로 발달 양 상을 살펴본 결과, 각기 다른 양상이 나타난 것에 주목할 필요 가 있다. 첫째로 언어이해 영역에서는 출생체중의 주 효과가 유의하게 나타나, 연령의 수준과 관계없이 출생체중에 따라 언 어이해 능력에 차이가 있었다. 영유아기의 언어이해 능력은 연 령에 관계없이 극소저출생체중아가 초극소저출생체중아보다 높은 경향성이 존재한다는 것이다. 이는 12 24개월경의 조산 아들이 정상군보다 언어 능력이 낮은 발달궤도를 보였다는 종 단 연구와도 일관되는 결과이다. ${ }^{26}$ 둘째로 시공간 영역에서 연 령과 출생체중의 상호작용 효과가 유의하게 나타났다. 즉, 시
공간 능력은 연령이 낮을 때 초극소/극소저출생체중아 간에 큰 차이가 없을지라도, 연령이 높아짐에 따라 극소저출생체 중아의 시공간 능력이 높아질 가능성이 나타났다. 이는 극소저 출생체중아의 경우 영유아기에 연령의 증가에 따라 시공간 능 력에 대한 발달 지연이 가역적으로 회복되는 경과를 보일 가 능성을 시사한다.

지능은 후천적인 훈련을 통해 증진시키는 것이 가능하다는 Sternberg ${ }^{27)}$ 의 관점이나 발달 지연 영유아의 인지조기중재를 통해 작업기억이나 시공간능력과 관련된 소검사 수행에서 긍 정적인 변화가 관찰되었다는 보고를 고려해 볼 때, ${ }^{28)}$ 초극소/ 극소저출생체중아의 영유아기 인지 발달에 대한 경과 예측은 치료적 개입에 효과적일 것으로 보이며, 본 연구의 결과 역시 활용될 수 있을 것으로 보인다. 예를 들어 언어이해 영역에 있 어 초극소저출생체중아인 영유아의 경우 경험에 의한 수용어 휘를 증가시키는 방향에 초점을 두고, 극소저출생체중아의 경우 수용어휘는 물론 범주화나 일반화와 관련된 개념 학습 까지 포함하여 개입하는 목표를 세울 수 있겠다. 또한 시공간 영역에서는 연령이 낮을 경우 공통적으로 시각-운동을 통합하 는 감각 훈련에 초점을 두고, 극소저출생체중아의 경우 연령이 증가함에 따라 문제해결, 인지적 유연성, 추론 및 계획과 같은 영역도 추가적으로 진행해 나가는 식의 차별적인 목표를 설 정할 수 있다. 추후 연구에서는 본 연구 결과에 대한 재검증 뿐만 아니라 세부 인지 영역별로 출생체중이나 연령에 따라 다 른 발달 양상을 고려하여 설계된 인지 개입의 프로그램이나 이 에 대한 효과성에 대한 연구가 필요할 것으로 보인다.

한편, 작업기억 영역에서는 시공간 영역과 달리 출생체중의 수준이나 연령과 관련된 유의한 설명력이 나타나지 않았다. 이는 저출생체중의 조산아 집단이 정상아 집단에 비해 작업기 억이 더 낮았다는 선행연구와는 별개로, ${ }^{8}$ 초극소/극소 저출생 체중아 내에서는 출생체중이나 연령에 따른 작업기억의 차이 는 크지 않을 수 있음을 의미한다. 이러한 결과는 K-WPPSIIV의 인지 세부 영역에 대한 신경심리학적 가설에 입각하여 논의해 볼 수 있다. 시공간 영역과 작업기억 영역에 공통적으 로 반영되는 중요한 인지능력 요소 중 하나로 시지각 능력을 들 수 있다. ${ }^{29)}$ 더불어 시공간 능력은 시각적 자극에 대한 추론 및 계획, 문제해결, 인지적 유연성과 같은 고차적 인지기능과 관련되는 것에 반해, 작업기억 영역은 단순한 시각적 자극에 대한 순간적인 기억력이나 반응 억제와 같은 실행기능을 반영 하는 것으로 알려져 있다. ${ }^{16-19)}$ 시각 피질의 성숙은 태내 초기 신경발달 과정과 출산 후 경험에 기초한 가소성이 결정적이라 는 선행연구를 고려할 때, ${ }^{30}$ 본 연구에서 초극소저출생체중아 의 평균 재태기간인 184.4일(약 25주)과 극소저출생체중아의 평균 재태기간인 211.6일(약 30주)의 차이로 인한 시각적 자극 
의 지각에서의 차이는 크지 않을 것이라고 유추할 수 있다. 이처럼 공통적인 시각적 능력에 큰 차이가 없다고 가정할 경 우, 두 영역의 차이에 해당하는 추론 및 계획, 인지적 유연성, 문제해결력 등의 고차적 인지기능은 출생체중에 기인한 영향 력이 높을 가능성을 추론할 수 있다. 하지만 이는 이론적 추 론이므로 추후 영상의학적 검사를 활용한 경험적 연구를 통해 확인될 필요가 있겠다.

본 연구의 의의는 다음과 같다. 지능과 연령 간 관계에서 출 생체중의 중재효과에 대해 최신판 지능평가도구로 처음으로 밝힌 연구로서, 조산아의 출생체중 수준이 전반적인 지적 능 력이나 시공간능력과 관련이 있을 뿐만 아니라, 시간의 흐름 에 따라 차별적인 발달적 궤도를 보일 수 있음을 밝혀, 인지 발 달에 대한 경과 예측에 대한 시사점을 주었다는 데 의의가 있 다. 또한 언어이해나 시공간능력과 같은 세부인지 영역별로 조산아의 출생체중이나 출생체중과 연령과의 상호작용을 살 펴봄으로써, 차별적인 개입의 방향성을 시사하였다는 점에 의 미가 있다. 이는 조산아의 인지 발달에 대한 경과를 예측하거 나 인지 조기 중재를 위한 세부 영역별 개입 프로그램을 구성 하는 데 활용될 수 있을 것으로 보인다.

아울러 본 연구의 제한점과 후속 연구를 위한 제언은 다음 과 같다. 첫째, 본 연구의 대상은 대학병원에서 초극소/극소저 출생체중아를 추적 관찰하며 연구 참여자를 모집하였으나 표본 크기 및 표집 방식에 있어 현실적인 제약이 있었다. 본 연 구에서는 전체지능과 시공간/언어이해/작업기억 영역에 대한 위계적 회귀분석을 위한 최소한의 표본 크기를 충족시켰으나, 고연령에서만 산출되는 지각추론/처리속도 영역은 위계적 회 귀분석을 위한 최소한의 표본 크기를 충족하지 못하여 분석 에서 제외되었다. 또한 연구 참여에 대한 동의 및 협조가 가능 한 대상을 중심으로 편의표집하는 과정에서 표집 오차가 더 커졌을 가능성도 배제할 수 없다. 따라서 추후 연구에서는 보 다 큰 표본을 확보하고 무선 표집을 통해 표집 오차를 최소화 한 연구가 필요할 것으로 보인다. 둘째, 본 연구는 연령을 포 함하여 분석하였으나 횡단 연구이기 때문에 조산아의 지능에 연령이나 출생체중이 미치는 영향을 단일한 시점에서만 살펴 볼 수 있었다. 따라서 추후에는 종단 연구를 통해 미숙아의 지능 발달이 연령에 따라 변화하는 양상이나, 출생체중이 인 지 발달의 위험 요인으로 작용하는 인과관계를 명확히 밝힐 필요가 있겠다. 셋째, 본 연구에서 사용된 지능평가도구인 KWPPSI-IV의 주요한 구성개념에는 신경심리학적인 인지처리 능력과 관련된 가설이 포함되며 신경발달학적 관점에 입각하 여 해석될 수 있으나, ${ }^{16-18)}$ 이는 직접적인 신경촬영술과 연계된 연구가 아니다. 따라서 추후에는 뇌영상 연구를 통해 저체중 조산아 아동의 인지적 저하 양상과 뇌발달의 관련성, 그 기전
에 대한 연구가 수행될 필요가 있을 것으로 보인다.

\section{결 론}

조산아의 출생체중과 연령이 지능에 미치는 영향을 살펴본 결과, 전체지능에 대한 연령과 출생체중의 상호작용 효과가 유 의하게 나타났다. 이는 극소저출생체중아의 지능이 저연령일 때 초극소저출생체중아와 유사하게 나타날지라도, 연령이 증 가함에 따라 전체지능에 대한 발달 지연이 가역적으로 회복 되는 경과를 보일 수 있음을 의미한다. 세부인지 영역에서는, 언어이해 능력에서 출생체중의 주효과가 유의하여 연령에 관 계없이 극소저출생체중아가 초극소저출생체중아보다 높은 언 어이해 능력을 보이는 경향이 나타났다. 또한 시공간 능력에 미 치는 출생체중과 연령의 상호작용 효과가 유의하였다. 이는 초 극소/극소저체중아인 미숙아가 영유아기에 출생체중 혹은 연 령에 따라 차별적인 인지 발달 궤도를 가진다는 잠재적인 가 능성을 제안하며, 이들의 세부적인 인지 발달에 대한 경과 예 측과 조기 중재에 있어 시사점을 주었다는 것에 의의가 있다.

중심 단어: 한국 웩슬러 유아지능평가 4판; 인지발달; 미숙아; 초극소저출생체중아; 극소저출생체중아.

\section{Acknowledgments}

이 논문은 2014년 정부(교육부)의 재원으로 한국연구재단의 지원 을 받아 수행된 연구임(NRF-2014S1A5A2A01013621).

\section{Conflicts of Interest}

The authors have no financial conflicts of interest.

\section{REFERENCES}

1) WHO: recommended definitions, terminology and format for statistical tables related to the perinatal period and use of a new certificate for cause of perinatal deaths. Modifications recommended by FIGO as amended October 14, 1976. Acta Obstet Gynecol Scand 1977;56:247-253.

2) Blencowe H, Cousens S, Oestergaard MZ, Chou D, Moller AB, Narwal R, et al. National, regional, and worldwide estimates of preterm birth rates in the year 2010 with time trends since 1990 for selected countries: a systematic analysis and implications. Lancet 2012;379: 2162-2172.

3) Askin DF, Wilson D. The high-risk newborn and family. In: Wong DL, Hockenberry MJ, Wilson D, editors. Wong's nursing care of infants and children. 8th ed. St. Louis: Mosby/Elsevier;2007. p.318.

4) Aylward GP. Cognitive and neuropsychological outcomes: more than IQ scores. Ment Retard Dev Disabil Res Rev 2002;8:234-240.

5) Taylor HG, Klein N, Minich NM, Hack M. Middle-school-age outcomes in children with very low birthweight. Child Dev 2000;71: 1495-1511.

6) Litt R, Joseph A, Gale R. Six year neurodevelopmental follow-up of very low birthweight children. Isr J Med Sci 1995;31:303-308.

7) Wang PW, Fang LJ, Tsou KI; Taiwan Infant Developmental Collaborative Study Group. The growth of very-low-birth-weight infants at 5 years old in Taiwan. Pediatr Neonatol 2014;55:114-119.

8) Wechsler D. Technical and interpretative manual: WPPSI-IV. New 
York: Pearson Inc.;2012.

9) Marlow N, Wolke D, Bracewell MA, Samara M; EPICure Study Group. Neurologic and developmental disability at six years of age after extremely preterm birth. N Engl J Med 2005;352:9-19.

10) Serenius F, Källén K, Blennow M, Ewald U, Fellman V, Holmström G, et al. Neurodevelopmental outcome in extremely preterm infants at 2.5 years after active perinatal care in Sweden. JAMA 2013;309: 1810-1820.

11) Voss W, Neubauer AP, Wachtendorf M, Verhey JF, Kattner E. Neurodevelopmental outcome in extremely low birth weight infants: what is the minimum age for reliable developmental prognosis? Acta Paediatr 2007;96:342-347.

12) Marret S, Marchand-Martin L, Picaud JC, Hascoët JM, Arnaud C, Rozé JC, et al. Brain injury in very preterm children and neurosensory and cognitive disabilities during childhood: the EPIPAGE cohort study. PLoS One 2013;8:e62683.

13) Lee HJ, Park HK. Neurodevelopmental outcome of preterm infants at childhood: cognition and language. Hanyang Med Rev 2016;36: $55-58$.

14) Park H, Seo Y, Lee J. A study of concurrent validities of K-WPPSIIV. Korean J Child Stud 2015;36:65-83.

15) Raiford SE, Coalson DL. Essentials of WPPSI-IV assessment. Hoboken: John Wiley \& Sons;2014.

16) Miller DC. School neuropsychological assessment and intervention. In: Miller DC, editor. Best practices in school neuropsychology: guidelines for effective practice, assessment, and evidence-based intervention. Hoboken: John Wiley \& Sons;2010. p.81-100.

17) Miller DC. Essentials of school neuropsychological assessment. Hoboken: John Wiley \& Sons;2013.

18) Miller DC, Maricle DE. The emergence of neuropsychological constructs into tests of intelligence and cognitive abilities. In: Flanagan DP, Harrison P, editors. Contemporary intellectual assessment: theories, tests, and issues. New York: Guilford Press;2012. p.800-819.
19) Chung SJ, Sung IK, Kim HJ, Woo YJ, Lee MH, Shin SM. Developmental test in children. J Korean Pediatr Soc 2002;45:817-821.

20) Martin A, Volkmar FR, Lewis M. Lewis's child and adolescent psychiatry: a comprehensive textbook. Philadelphia: Lippincott Williams \& Wilkins;2007.

21) Lim YJ. The clinical utility of Korean Bayley Scales of infant and toddler development-III: perspective of the preterm infant [dissertation]. Seoul: Ewha Womans Univ.;2015.

22) Park HW, Lee KO, Ahn DH. K-WPPSI-IV Wechsler Preschool and Primary Scale of Intelligence. Seoul: Hakjisa;2016.

23) Aiken LS, West SG, Reno RR. Multiple regression: testing and interpreting interactions. Newbury Park: Sage Publications;1991.

24) Soper DS. A-priori sample size calculator for hierarchical multiple regression [cited 2017 Mar 24]. Available from: http://www.danielsoper.com/statcalc/calculator.aspx?id=16.

25) Choi BN. The relationship between intelligence and social competence of young children. Ulsan: University of Ulsan;2014.

26) Sansavini A, Guarini A, Savini S, Broccoli S, Justice L, Alessandroni R, et al. Longitudinal trajectories of gestural and linguistic abilities in very preterm infants in the second year of life. Neuropsychologia 2011;49:3677-3688.

27) Sternberg RJ. Intelligence, wisdom, and creativity: their natures and interrelationships. In: Linn RL, editor. Intelligence: measurement, theory, and public policy. Urbana, Chicago: University of Illinois Press;1989. p.119-146.

28) Choi EM, Park HW. The effects of early cognitive intervention program for infants children with developmental delays. Korean Psychol Assoc 2016;2016:297.

29) Sattler JM. Assessment of children: cognitive foundations. 5th ed. San Diego: JM Sattler;2008.

30) Espinosa JS, Stryker MP. Development and plasticity of the primary visual cortex. Neuron 2012;75:230-249. 